\title{
KOMPARASI PERAN KURIKULUM PENGKADERAN \\ PMII DAN IMM UIN SUNAN KALIJAGA \\ DALAM PEMBENTUKKAN KARAKTER MAHASISWA
}

\section{AHMAD BUSTOMI}

\begin{abstract}
The background of this research is the existency of extra campus organizations which have an ideology contradicting with Pancasila as the Nation Ideology and its democracy system which according to researcher it strongly threatens the integrity of NKRI. On the other side, there are many news in various media which issues the confusions between Islamic Mission becoming the spirit of Islamic students organizations and the practice of some cadres in field such as fighting among islamic students and destroying campus or public fasilities. The recruitment curriculum of cadre is very important thing to be analyzed more deeply considering from where it will be seen the direction of this students' movement working, the background and spirit of organizations. Therefore, the researcher focuses on something important to be analyzed especially related to the role of Islamic student organization of extra campus on the forming of students' character of PMII and IMM cadre in UIN Sunan Kalijaga. The selection of organization around UIN Sunan Kalijaga is chosen because of the location in Yogyakarta, in which mostly becomes a place for the establishment of student organizations and UIN Sunan Kalijaga itself has a massive organization climate. Especially thee wo organizations is the bioloical children of two of the largest Islamic organizations in Indonesia, namely NU and Muhammadiyah, which makes it a more Islamic student oranization than any other Islamic student organization.
\end{abstract}

Kata Kunci: Kurikulum Pengkaderan, Karakter Mahasiswa

\section{A. Pendahuluan}

Penelitian ini berangkat dari adanya organisasi mahasiswa Islam tertentu yang tidak sepakat dengan demokrasi yang diterapkan di Indonesia bahkan yang secara frontal ketidaksepakatannya terhadap pancasila sebagai dasar negara, teman-teman aktifis organisasi mahasiswa Islam yang golongan ini biasanya lebih mengamini dasar negara Indonesia menjadi Islam “tidak lagi pancasila”, pancasila hanya dianggap sebagai suatu dasar negara yang tidak seharusnya dipakai, bid'ah, tidak 
sesuai dengan dasar negara yang diterapkan oleh Nabi dengan berdalih Indonesia yang mayoritas muslim, dimana para kader golongan ini menjustis bahwa Islam menjadi sebuah keniscayaan dijadikan sebagai dasar negara, bukan Pancasila yang sejatinya hal ini sangat mengancam keutuhan NKRI.Disisi lain banyak berita di berbagai media yang memunculkan kerancuan-kerancuan antara misi Islam yang menjadi spirit organisasi mahasiswa Islam dengan praktik para kader di lapangan seperti tauran antar mahasiswa Islam, perusakan terhadap kampus atau fasilitas-fasilitas umum.

Kurikulum perkaderan menjadi hal yang paling pokok untuk dikaji lebih, mengingat dari sanalah akan terlihat arah gerakan mahasiswa ini berjalan, latar belakangnya serta spirit berorganisasinya. Oleh karena itu penting untuk dikaji terutama terkait perannya dalam pembentukkan karakter mahasiswa. Di samping pemaparan di atas, muncul pula fenomena manarik mengenai kecenderungan-kecenderungan terkait perubahan karakter yang terjadi pada mahasiswa selepas dari kegiatan pengkaderan, seperti: mulai pekanya mahasiswa terhadap fenomena sekitar terutama mengenai kebijakan-kebijakan yang terjadi di sekitarnya, baik kebjakan kampus, pemerintah bahkan kebijakan skop kecil seperti keputusan-keputusan dosen di kelas, perubahan dari yang tadinya tidak pernah solat berjamah menjadi mulai dan bahkan rajin jamaah pasca pengkaderan, ada yang mulai keranjingan baca buku bahkan adapula yang sebaliknya dalam arti melakukan tindakan-tindakan destruktif baik untuk dirinya sendiri maupun lingkungan seperti muncul perilaku menyepelekan dosen, telat masuk kuliah, berpakaian kurang syar'i, over action dalam merespon kebijakan-kebijakan kampus seperti mencorat-coret dinding kampus, demo sampai memecahkan kaca kampus dan sebagainya, dengan demikian ada implikasi pada mahasiswa dalam proses pengkaderan sebelumnya tersebut. UIN Sunan Kalijaga menjadi 
kampus yang harus diteliti karena letaknya yang strategis yang mana disamping secara geografis berada di Yogyakarta yang menjadi kota pendidikan, disana pula menjamur organisasi secara massif. PMII dan IMMmerupakan salah satu organisasi yang eksistensinya tidak diragukan lagi dan menghegemoni di berbagai perguruan tingi menjadi penting untuk dikaji lebih dalam mengenai peran kurikulum pengkaderannya dalam membentuk karakter kader.Terlebih dua organisasi ini merupakan anak kandung dari dua organisasi Islam terbesar di Indonesia yaitu NU dan Muhammadiyah yang menjadikannya sebagai organisasi mahasiswa Islam yang lebih digandrungi ketimbang organisasi mahasiswa Islam lainnya.

\section{B. LANDASAN TEORI}

1. Kurikulum Pengkaderan

Prof. Dr. H. Engkoswara, M. Ed, guru besar Universitas Pendidikan Indonesia telah mencoba untuk merumuskan perkembangan pengertian kurikulum dalam menggunakan formulaformula sebagai berikut.

a. $\mathrm{K}=\ldots \ldots . . .$. , artinya jarak yang harus ditempuh oleh pelari.

b. $\mathrm{K}=\sum \mathrm{MP}$, artinya kurikulum adalah sejumlah mata pelajaran yang harus ditempuh oleh peserta didik

c. $\mathrm{K}=\sum \mathrm{MP}+\mathrm{KK}$, artinya kurikulum adalah sejumlah mata pelajaran dan kegiatan-kegiatan yang eah direncanakan sekoah yang harus ditempuh oleh peserta didik.

d. $K=\sum M P+K K+S S+T P$, artinya kurikulum adalah sejumlah mata pelajaran dan kegiatan-kegiatan dan segala sesuatu yang berpengaruh terhadap pembentukkan pribadi peserta didik sesuai dengan tujuan pendidikan yang telah ditetapkan oleh pemerintah atau sekolah. ${ }^{1}$ 
Dari penjabaran tersebut nampak jelas perkembangan kurikulum. Lalu bagaimana dengan kurikulum pengkaderan?.Berangkat dari penjelasan Engkoswara di atas, maka dapat dikatakan bahwa kurikulum pengkaderan adalah sejumlah materi pegkaderan dan kegiatan-kegiatan dan segala sesuatu yang berpengaruh terhadap pembentukkan pribadi kader sesuai dengan tujuan pengkaderan yang telah ditetapkan oleh organisasi.Sedangkan dalam istilah Saylor dan Alexander bila ditarik dalam dunia pengkaderan maka yang dimaksud kurikulum pengkaderan adalah merupakan keseluruhan usaha yang dilakukan oleh lembaga pendidikan (ORMAWA) utuk mencapai tujuan yang telah diharapkan. Definisi tersebut menggambarkan bahwa kurikulum bukan sekedar materi pengkaderan saja, melainkan termasuk proses belajar mengajar, dan usaha lain yang berkaitan dengan organisasi. IMM jika dilihat dari pemaparan di atas, maka setidaknya melakukan dua hal, pelatihan (DAD) dan penugasan (kepanitiaan dan struktural kampus)

2. Implementasi dan Implikasi Kurikulum

Jika kurikulum adalah programnya, maka pembelajaran merupakan implementasinya.Jika kurikulum adalah teorinya, maka pembelajaran adalah praktiknya.Oleh karena itu, maka dapat disimpuDADanbahwa implementasi kurikulum pengkaderan terletak pada pelatihannya, karena disanalah letak pembelajaran berlangsung dalamIMM.Pembelajaran atau dalam bahasa pengkaderan disebut dengan pelatihan memiliki berbagai cara/metode dengan keunggulan dan kekurangannya masing-masing. Adapun yang dimaksud dengan metode pembelajan adalah cara yang digunakan guru untuk menyampaikan pelajaran kepada siswa. ${ }^{2}$ Macam-macam metode pembelajaran diantaranya adalah: a. Ceramah. b. Tanya jawab. c. Diskusi d. Demonstrasi dan eksperimen. e. Tugas belajar dan resitasi f. 
Kerja kelompok. g. Sosiodrama (role playing). h. Pemecahan masalah (problem solving) i. Sistem regu j. Karya wisata. k. Manusia sumber. 1.Survei masyarakat. m. Simulasi. n. Studi kasus. o. Tutorial. p. Curah gagasan. q. Studi bebas. r. Kelompok tanpa pemimpin. s. Latihan (drill). t. Latihan kepekaan. ${ }^{3}$

Implikasi kurikulum pengkaderan berarti berbicara mengenai implikasi dari sebuah pembelajaran/pelatihan dalam dunia aktifis.Implikasi tersebut setidaknya berkaitan dengan tingkah laku, kondisi tes dan standar (ukuran). ${ }^{4}$

3. Karakter

Karakter dari beberapa buku yang Peneliti baca banyak yang menyatakan bahwa karakter berasal dari bahasa Yunani ada pula yang mengklaim berasal dari bahasa latin bahkan ada yang berani mengatakan dari bahasa perancis, namun terlepas dari perbedaanperbedaan yang muncul dari beberapa ahli dan dari asal usul karakter bisa ditarik kesimpulan bahwa karakter adalah ciri khas yang membedakan satu orang dan orang lainnya baik dalam hal berfikir, bersikap maupun merasa. Adapun jika diringkas karakter bangsa ini adalah sebagai berikut :5

\begin{tabular}{|c|c|l|}
\hline NO & NILAI & DESKRIPSI \\
\hline 1 & Religius & $\begin{array}{l}\text { Sikap dan prilaku yang patuh dalam melaksanakan } \\
\text { ajaran agama yang dianutnya, toleran terhadap } \\
\text { pelaksanaan ibadah agama lain, dan hidup rukun } \\
\text { denganp emeluk agama lain. }\end{array}$ \\
\hline 2 & Jujur & $\begin{array}{l}\text { Prilaku yang didasarkan pada upaya menjadikan } \\
\text { dirinya sebagai orang yang selalu dapat dipercaya } \\
\text { dalamp erkataan, tindakan danp ekerjaan. }\end{array}$ \\
\hline 3 & Toleransi & $\begin{array}{l}\text { Sikap dan tindakan yang menghargai perbedaan } \\
\text { agama, suku, etnis, pendapat, sikap, dan tindakan } \\
\text { orang lain yang berbeda dari dirinya. }\end{array}$ \\
\hline 5 & Kerjakeras & $\begin{array}{l}\text { Tindakan yang menunjukkan prilaku tertib dan patuh } \\
\text { pada berbagai ketentuan dan peraturan. } \\
\text { Perilaku yang menunjukkan upaya sungguh-sungguh } \\
\text { dalam mengatasi berbagai hambatan belajar dan tugas, }\end{array}$ \\
\hline
\end{tabular}




\begin{tabular}{|c|c|c|}
\hline & & serta menyelesaikan tugas dengan sebaik-baiknya. \\
\hline 6 & Kreatif & $\begin{array}{l}\text { Berfikir dan melakukan sesuatu untuk menghasikan } \\
\text { cara atau hasil baru dari sesuatu yang telah dimiliki. }\end{array}$ \\
\hline 7 & Mandiri & $\begin{array}{l}\text { Sikap dan perilaku yang tidak mudah tergantung pada } \\
\text { oranglaindalammenyelesaikantugas-tugas. }\end{array}$ \\
\hline 8 & Demokratis & $\begin{array}{l}\text { Cara berfikir, bersikap, danbertindak yang } \\
\text { menilaisamahakdankewajibandirinyadan orang lain. }\end{array}$ \\
\hline 9 & $\begin{array}{l}\text { Rasa ingin } \\
\text { tau }\end{array}$ & $\begin{array}{l}\text { Sikapdantindakan yang } \\
\text { selaluberupayauntukmengetahuilebihmendalamdanme } \\
\text { luasdarisesuatu yang dipelajarinya, dilihat, } \\
\text { dandidengar. }\end{array}$ \\
\hline 10 & $\begin{array}{c}\text { SemangatKe } \\
\text { bangsaan }\end{array}$ & $\begin{array}{l}\text { Cara berfikir, bertindakdanberwawasan yang } \\
\text { menempatkankepentinganBangsadan Negara di } \\
\text { ataskepentingandiridankelompoknya. }\end{array}$ \\
\hline 11 & $\begin{array}{l}\text { Cintatanah } \\
\text { air }\end{array}$ & $\begin{array}{l}\text { Cara berfikir, bersikap, danberbuat yang } \\
\text { menunjukkankesetiaan, kepedulian, danpenghargaan } \\
\text { yang tinggiterhadapbahasa, lingkunganfisik, sosial, } \\
\text { budaya, ekonomi, danpolitikbangsa. }\end{array}$ \\
\hline 12 & $\begin{array}{c}\text { Menghargai } \\
\text { prestasi }\end{array}$ & $\begin{array}{l}\text { Sikapdantindakan yang } \\
\text { mendorongdirinyauntukmenghasiDADansesuatu yang } \\
\text { bergunabagimasyarakat, danmengakui, } \\
\text { sertamenghormatikeberhasilan orang lain. }\end{array}$ \\
\hline 13 & $\begin{array}{l}\text { Bersahabat / } \\
\text { komunikatif }\end{array}$ & $\begin{array}{l}\text { Tindakan yang menunjukkan rasa senangberbicara, } \\
\text { bergaul, danbekerjasamadengan orang lain. }\end{array}$ \\
\hline 14 & Cintadamai & $\begin{array}{l}\text { Sikap, Perkataan, dantindakan yang } \\
\text { menyebabkanseseorang lain } \\
\text { merasasenangdanamanataskehadirandirinya. }\end{array}$ \\
\hline 15 & $\begin{array}{c}\text { Gemarmemb } \\
\text { aca }\end{array}$ & $\begin{array}{l}\text { Kebiasaanuntukmenyediakanwaktuuntukmembacaber } \\
\text { bagaibacaanyagmemberikankebajikanbagidrinya. }\end{array}$ \\
\hline 16 & $\begin{array}{c}\text { Pedulilingku } \\
\text { ngan }\end{array}$ & $\begin{array}{l}\text { Sikapdantindakan yang } \\
\text { berupayamencegahkerusakanlingkunganalamdisekitar } \\
\text { nya, danmengembangkanupaya- } \\
\text { upayauntukmemperbaikikerusakanalam yang } \\
\text { sudahterjadi. }\end{array}$ \\
\hline 17 & Pedulisosial & $\begin{array}{l}\text { Sikapdantindakan yang } \\
\text { inginselalumemberibantuanpada orang } \\
\text { laindanmasyarakat yang membutuhkan. }\end{array}$ \\
\hline 18 & $\begin{array}{l}\text { Tanggungja } \\
\text { wab }\end{array}$ & $\begin{array}{l}\text { Sikapdanperilakuseseoranguntukmelaksanakantugasda } \\
\text { nkewajibannya, yang seharusnyadialakukan, } \\
\text { terhadapdirisendiri, masyarakat, lingkungan (alam, } \\
\text { sosialdanbudaya), Negara danTuhan YME. }\end{array}$ \\
\hline
\end{tabular}




\section{Pembahasan}

Dari hasil penelitian, peneliti menemukan bahwa perbandingan kurikulum antara PMII dan IMM UIN Sunan Kalijaga adalah sebagai berikut:

\begin{tabular}{|c|c|c|c|}
\hline & TUJUAN & ISI & EVALUASI \\
\hline PMII & $\begin{array}{l}\text { a. Menciptakan kader bangsa } \\
\text { yang progresif bagi kaum } \\
\text { muda / mahasiswa Indonesia } \\
\text { b. Pengenalan dan proses awal } \\
\text { menjadi anggota PMII } \\
\text { c. Menumbuhkan paradigma } \\
\text { kritis transformatif terhadap } \\
\text { kader dalam melihat realitas } \\
\text { sosial masyarakat. } \\
\text { d. Menciptakan ruang-ruang } \\
\text { diskusi diantara kader } \\
\text { e. Sebagai sarana pendidikan } \\
\text { non formal bagi mahasiswa. }\end{array}$ & $\begin{array}{l}\text { a. Analisis diri } \\
\text { b. Genealogi } \\
\text { dan } \\
\text { keorganisasia } \\
\text { n PMII } \\
\text { c. Aswaja dan } \\
\text { Keislaman } \\
\text { d. Nilai Dasar } \\
\text { Pergerakan } \\
\text { (NDP) } \\
\text { e. Analisa } \\
\text { Sosial }\end{array}$ & $\begin{array}{l}\text { a.Evaluasi } \\
\text { harian } \\
\text { b.Evaluasi } \\
\text { keseluruh } \\
\text { an }\end{array}$ \\
\hline IMM & $\begin{array}{l}\text { Membentuk karakter dan } \\
\text { kepribadian serta mutu anggota } \\
\text { hingga mencapai kualifikasi } \\
\text { kader IMM yang mempunyai } \\
\text { wawasan tingkat Komisariat dan } \\
\text { Cabang serta internalisasi dasar- } \\
\begin{array}{l}\text { dasar Islam dan meletakkan } \\
\text { dasar } \\
\text { intelektualitas. }\end{array}\end{array}$ & $\begin{array}{l}\text { a. Kepemimpin } \\
\text { an/ledership } \\
\text { b. Intelektualita } \\
\mathrm{s} \\
\text { c. Keislaman/r } \\
\text { eligius } \\
\text { d. Kemuhamma } \\
\text { diyahan } \\
\text { e. Ke-IMMan }\end{array}$ & $\begin{array}{l}\text { a.Evaluasi } \\
\text { harian } \\
\text { b.Evaluasi } \\
\text { keseluruh } \\
\text { an }\end{array}$ \\
\hline
\end{tabular}

Implementasi kurikulum secara umum sama saja dari segi penugasan maupun pelatihan, namun jika dilihat pada saat pelatihan maka akan terlihat sedikit perbedaan, yaitu seperti yang terlihat pada bagan berikut ini: 


\begin{tabular}{|c|c|c|}
\hline & MOT/INSTRUKTUR/FASILITATOR & $\begin{array}{c}\text { METODE } \\
\text { PELATIHAN }\end{array}$ \\
\hline PMII & $\begin{array}{l}\text { Pemandu dalam PKD disebut fasilitator } \\
\text { berjumlah banyak disesuaikan denan jumlah } \\
\text { yang dibutuhkan (jumlah pembaian grup } \\
\text { kecil) yang bertugas mengatur jalannya PKD, } \\
\text { memantik materi sebelum disampaikan oleh } \\
\text { pemateri dan pendamping ketika fgd/panel. }\end{array}$ & $\begin{array}{l}\text { Ceramah, tanya } \\
\text { jawab, fgd/sgd, } \\
\text { panel, dinamika } \\
\text { grup, debat. }\end{array}$ \\
\hline IMM & $\begin{array}{l}\text { Pemandu dalam DAD disebut instruktur } \\
\text { berjumlah } 3 \text { orang, bertugas memberikan } \\
\text { pengantar sebelum pemateri memberi materi, } \\
\text { memandu jalannya kelas dan pendamping } \\
\text { fgd/panel, mencari pemateri hingga } \\
\text { bertanggung jawab sampai } 6 \text { bulan pasca } \\
\text { pengkaderan. }\end{array}$ & $\begin{array}{l}\text { Ceramah, tanya } \\
\text { jawab, fgd/sgd, } \\
\text { panel, dinamika } \\
\text { grup, debat. }\end{array}$ \\
\hline
\end{tabular}

Implikasi kurikulum dan implementasinya setiap organisasi terhadap karakter kader tentunya berbeda-beda. Hal ini terlihat dalam bagan di bawah ini:

\begin{tabular}{|l|l|}
\hline & \multicolumn{2}{|c|}{ KARAKTER } \\
\hline PMII & $\begin{array}{l}10 \text { karakter (religius, toleransi, disiplin, demokratis, semangat } \\
\text { kebangsaan, cinta tanah air, bersahabat/komunikatif, peduli social, } \\
\text { peduli lingkungan dan tanggug jawab) }\end{array}$ \\
\hline IMM & $\begin{array}{l}\text { karakter (religius, toleransi, disiplin, menghargai prestasi, } \\
\text { bersahabat/komunikatif, peduli social dan tanggung jawab) }\end{array}$ \\
\hline
\end{tabular}

D. KESIMPULAN

1. Tujuan PKD adalahmenciptakan kader bangsa yang progresif bagi kaum muda / mahasiswa indonesia, pengenalan dan proses awal menjadi anggota PMII, menumbuhkan paradigma kritis transformatif terhadap kader dalam melihat realitas sosial masyarakat, menciptakan 
ruang-ruang diskusi diantara kader dan sebagai sarana pendidikan non formal bagi mahasiswa. Sedangkan tujuan DAD adalah membentuk karakter dan kepribadian serta mutu anggota hingga mencapai kualifikasi kader IMM yang mempunyai wawasan tingkat Komisariat dan Cabang serta internalisasi dasar-dasar Islam dan meletakkan dasar pemahaman intelektualitas. Materi dalam PKD terdiri dari analisis diri, genealogi dan keorganisasian PMII, nilai dasar pergerakan (NDP), analisis sosial, aswaja dan keislaman. Sedangkan dalam DAD terdiri dari kepemimpinan/ledership, intelektualitas, keislaman/religius, kemuhammadiyahan dan KeIMMan. kemudian jika dilihat dari segi evaluasi secara umum sama.

2. Dalam pelatihan (PKD dan DAD) secara umum sama, Pemandu dalam DAD disebut Instruktursedangkan dalam PKD disebut fasilitator, Jumlahnya dalam PKD menyesuaikan sedangkan dalam DAD 3 orang, sedangkan tugasnya dalam PKD adalah bertugas mengatur jalannya PKD, memantik materi sebelum disampaikan oleh pemateri dan pendamping ketika fgd/panel sedikit berbeda dengan instruktur dalam DAD yaitu memberikan pengantar sebelum pemateri memberi materi, memandu jalannya kelas dan pendamping fgd/panel, mencari pemateri hingga bertanggung jawab sampai 6 bulan pasca pengkaderan.Metode yang digunakan dalam mentransformasikan materi antara PMII dan IMM secara umum sama.

3. Implikasi dari kurikulum pengkaderan baik melalui pelatihan maupun penugasan memunculkan10 karakter dalam diri kader PMII sedangkan IMM 7 karakter. 
Penulis : Ahmad Bustomi S.Pd.I (Institut Agama Islam Negeri Bengkulu)

\section{DAFTAR PUSTAKA}

Hamdani, Strategi Belajar Mengajar, Bandung: Pustaka Setia, 2011.

Hamalik, Oemar, Perencanaan Pengajaran Berasarkan Pendekaan Sistem, Jakarta: Bumi Aksara, 2011.

Neuman, W. Lawrence, Metodolog Penelitian Sosial: Pendekatan Kualitatif dan Kuantitatif, Jakarta: Indeks, 2015.

Sistem Pengkaderan Ikatan (SPI) Ikatan Mahasiswa Muhammadiyah, Jakata: Dewan Pimpinan Pusat Ikatan Mahasiswa Muhammadiyah, 2011.

Sugiyono, Metode Penelitian Manajemen, Bandung: Alfabeta, 2013.

Suparlan, Tanya Jawab Pengembangan Kurikulum \& Materi Pembelajaran, Jakarta: Bumi Aksara, 2012.

Tanzeh, Ahmad, Metodologi Penelitian Praktis, Yogyakarta: Teras, 2011.

Wibowo, Agus, Pendidikan Karakter Strategi Membangun Karakter Bangsa Berperadaban, Yogyakarta: Pustaka Pelajar, 2012.

Zubaedi, Desain Pendidikan Karakter "Konsepsi dan Aplikasinya dalam Lembaga Pendidikan", Jakarta: Kencana Prenada Media Group, 2012.

\footnotetext{
1Suparlan, Tanya Jawab Pengembangan Kurikulum \& Materi Pembelajaran, (Jakarta: Bumi Aksara, 2012), hlm. 35-36.

${ }^{2}$ Hamdani, Strategi Belajar Mengajar , (Bandung: Pustaka Stia, 2011), hlm. 80.

3Ibid., hlm. 83.

${ }^{4}$ Oemar Hamalik, Perencanaan Pengajaran Berasarkan Pendekaan Sistem, (Jakarta: Bumi Aksara, 2011), hlm. 111.

5Peneliti ambil dari buku karangan Agus Wibowo, Pendidikan Karakter Strategi Membangun Karakter Bangsa Berperadaban, (Yogyakarta: Pustaka Pelajar, 2012), hlm. 4344, namun peneliti sedikit merubah kata-kata pada tabel guna menyesuaikan dengan bahasa peneliti. Bisa dilihat juga pada buku karangan Zubaedi, Desain Pendidikan Karakter "Konsepsi dan Aplikasinya dalam Lembaga Pendidikan", (Jakarta: Kencana Prenada Media Group, 2012), hlm. 74-76.
} 